\title{
Determinants of Enterprise Performance in Latin America and the Caribbean: What Does the Micro-Evidence Tell Us?
}

\author{
Matteo Grazzi, Carlo Pietrobelli, and Adam Szirmai
}

After a decade of relatively strong performance, growth in Latin America and the Caribbean (LAC) has begun to taper. This slowdown is even more worrisome considering the long-run economic performance of the region, where it is evident that there is difficulty in catching up with developed economies and even just keeping pace with other emerging regions. Over the last half-century, per capita income in Latin America has stagnated relative to the United States, while in East Asian countries ${ }^{1}$ it has grown steadily since 1960, reaching a level that is almost half of current US levels. The expected fall in commodity prices may further hinder LAC's economic performance.

\footnotetext{
M. Grazzi

Inter-American Development Bank

e-mail: matteog@iadb.org

C. Pietrobelli
}

Inter-American Development Bank and University Roma Tre

e-mail: carlop@iadb.org

A. Szirmai

UNU-MERIT

e-mail: szirmai@merit.unu.edu

(C) Inter-American Development Bank 2016

M. Grazzi and C. Pietrobelli (eds.), Firm Innovation

and Productivity in Latin America and the Caribbean,

DOI 10.1057/978-1-349-58151-1_1 
Table 1.1 Growth accounting: LAC vs. comparison countries (1960-2011) (\%)

\begin{tabular}{lllll}
\hline Country/ region & $\Delta$ GDP per capita & $\Delta$ Factor accumulation & $\Delta$ TFP & $\%$ share \\
\hline Average & $(a)$ & $(b)$ & $(a-b=c)$ & $(c / a)$ \\
\hline Latin America and the & 1.79 & 1.80 & -0.01 & $-0.6 \%$ \\
Caribbean & & & & \\
East Asia and Pacific & 3.69 & 2.85 & 0.83 & $22.5 \%$ \\
United States & 1.99 & 1.21 & 0.78 & $39.2 \%$ \\
China & 6.04 & 4.21 & 1.83 & $30.3 \%$ \\
Finland & 2.74 & 1.44 & 1.30 & $47.4 \%$ \\
\end{tabular}

Source: Authors' elaboration on data from Feenstra et al. (2015)

Notes: The LAC countries are Antigua and Barbuda, Argentina, Bahamas, Barbados, Belize, Bolivia, Brazil, Chile, Colombia, Costa Rica, Dominica, Dominican Republic, Ecuador, El Salvador, Grenada, Guatemala, Honduras, Jamaica, Mexico, Panama, Paraguay, Peru, St. Kitts \& Nevis, St. Lucia, St. Vincent \& the Grenadines, Suriname, Trinidad \& Tobago, Uruguay, and Venezuela. The East Asia and Pacific countries are Australia, Brunei, Cambodia, China, Fiji, Hong Kong, Indonesia, Japan, Laos, Macao, Malaysia, Mongolia, New Zealand, Philippines, Singapore, South Korea, Thailand, and Vietnam. Physical capital and human capital are considered productive factors in the production function

This tapering raises various questions. For example, what is behind LAC's disappointing performance? And, why have other regions developed so much more rapidly than LAC? The central argument of this book is that answering such questions requires going beyond analyzing macroeconomic trends to analyzing the micro-dynamics of development. The chapters focus on firmlevel sources of productivity growth. How are they related to the characteristics and strategies of firms? To what extent are productivity gains determined by better production methods, organizational improvements, firm-level innovation, learning, and capability development? Finally, what are the implications of microeconomic analysis for industrial and innovation policy?

Following the logic of the aggregate production function, factors of accumulation (capital and labor) and productivity (taken as a measure of technological progress) explain economic growth. A simple growth accounting exercise confirms recent economic research: despite years of rising factor accumulation, slow productivity growth is at the root of LAC's weak overall performance (Fernández-Arias 2014; Crespi et al. 2014; Pagés 2010). Between 1960 and 2011, GDP per capita in LAC grew at $1.79 \%$, just below the rate for the United States over the same time period. The region was also able to outpace the United States in terms of factor accumulation. However, in the USA, total factor productivity (TFP) grew at $1.21 \%$, while it stagnated in LAC, more than compensating for the lower factor accumulation. Thus, TFP can clearly be blamed for the LAC region's inability to catch up with US GDP per capita (Table 1.1). ${ }^{2}$ 


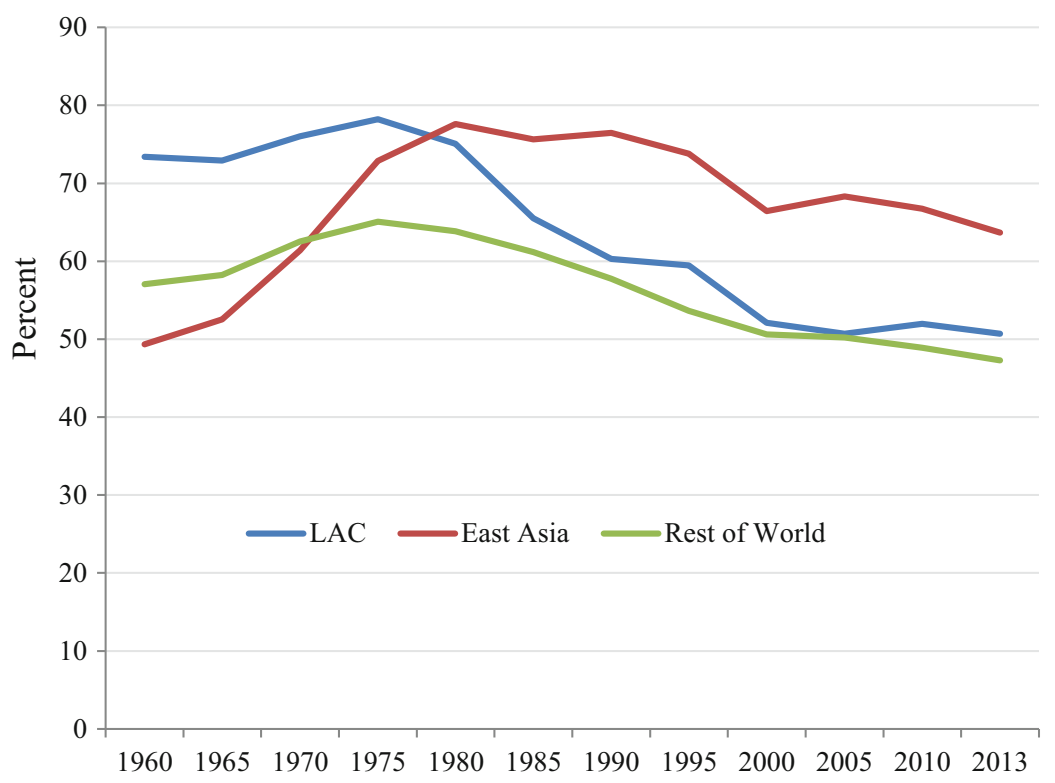

Fig. 1.1 TFP relative to the United States (1960-2013) (Source: FernándezArias 2014)

The LAC region's weak TFP performance is a stark contrast to other countries that were at similar development levels in 1960 but have since been able to converge toward US levels. For example, in Finland, TFP increased to 69 from $50 \%$ of the US level over the past 54 years, while in South Korea it went to 63 from $20 \%$ over the same period. In fact, the East Asian countries successfully boosted TFP relative to the United States from $49 \%$ in 1960 to $78 \%$ in 1980 and, after some decline, they were at $64 \%$ in 2013 (Fig. 1.1). The story for LAC is the opposite: between 1960 and 2011, GDP per capita growth in LAC was only sustained by factor accumulation, not by TFP growth, and productivity declined from $73 \%$ of US TFP in 1960 to only $51 \%$ in 2013 .

While the aggregate picture of LAC reveals overall weak performance in terms of productivity, analysis by country shows remarkable heterogeneity. Figure 1.2 plots the annual TFP growth of LAC countries between 2000 and 2011 against the productivity (TFP) gap relative to the United States in 2011. On the whole, since 2000, average productivity growth in the LAC region has declined by 0.04 percent per year. However, not all LAC 


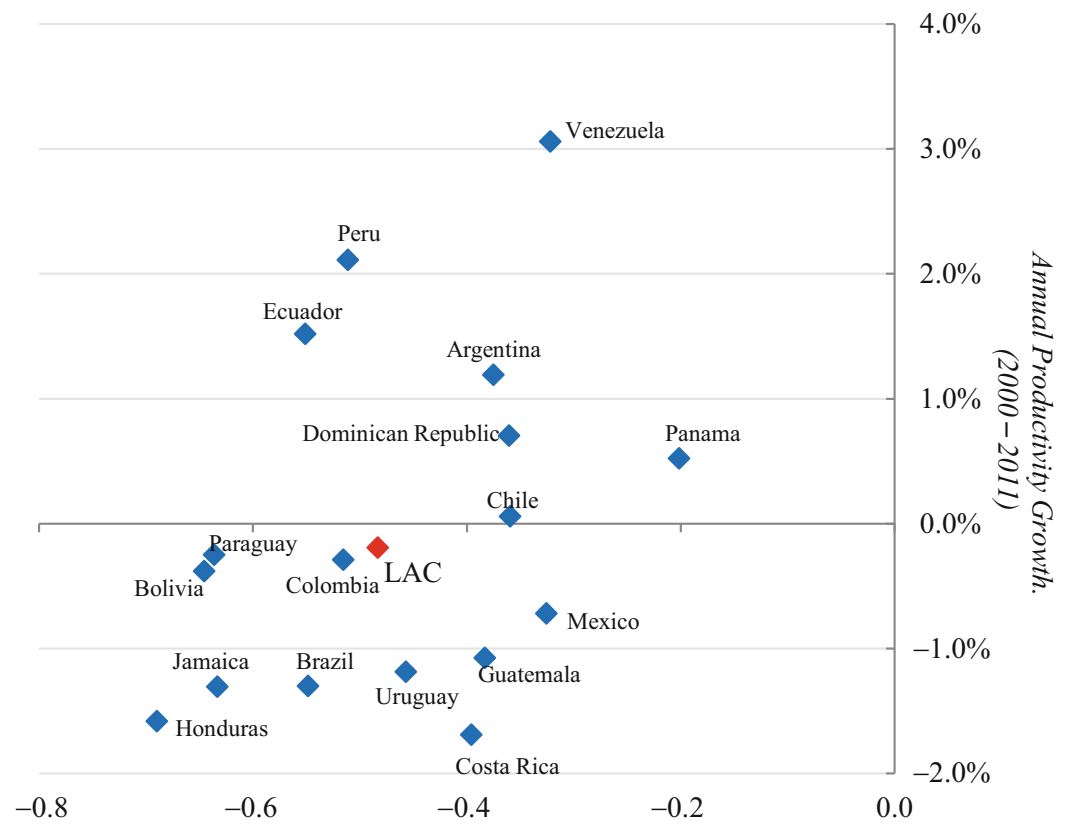

Productivity Gap Relative to the United States (2011)

Fig. 1.2 Productivity performance by country (2000-2011) (Source: FernándezArias 2014)

countries have followed this pattern. Honduras, for example, has seen a dramatic decline in absolute productivity growth (1.6 percent per year) since 2000 relative to a high productivity gap with the United States $(69$ percent in 2011). Other Central American countries, such as Costa Rica and Guatemala, recorded similar negative productivity growth, although with much narrower productivity gaps ( 40 percent relative to the United States). In contrast, South American countries tended to see more positive productivity growth, with the exception of Brazil and Uruguay where productivity declines over 1 percent per year.

The macro-evidence presented so far clearly indicates that LAC countries have been growing at lower rates than some other emerging regions and that they are failing to efficiently combine production inputs. If economic growth based on factor accumulation is subject to diminishing returns and successful catch-up requires fast productivity growth (Easterly and Levine 2001; Hall and Jones 1999; Klenow and Rodriguez-Clare 
1997), the fact that LAC countries have not been able to significantly increase their productivity is particularly worrisome. Indeed, this led us to investigate the reasons. In summary, what explains productivity and its evolution over time?

The research on this key issue is vast and has expanded in recent years (Syverson 2011). Many studies use macroeconomic data to estimate aggregate production functions and obtain the results we have described. However, the economic performance of a country or sector ultimately depends on decisions made at the firm level and this should explicitly be taken into account. Therefore, a disaggregated enterprise-level approach is necessary to obtain a deeper and more complete understanding of the dynamics of productivity growth (Foster et al. 2001). When the microeconomic dimension is introduced into the analysis, the economic literature has shown that firm productivity growth is essentially driven by two factors: reallocation of resources across firms; and within-firm efficiency improvements (Dollar et al. 2005; Bergoeing and Repetto 2006). ${ }^{3}$

The first factor, reallocation across firms, is only possible when resources can be easily allocated to different activities in the presence of smoothly functioning markets (Busso et al. 2013). In this context, the competition generates Schumpeterian creation and destruction processes, both within the same sector and across sectors. In the latter case, the process is expected to reshape economies toward more productive structures by shifting resources from less to more productive sectors. However, this shift does not appear to have happened in LAC in recent years, which led McMillan et al. (2014) to conclude that, during 1990-2005, the LAC region experienced significant productivity gains within the same sectors, but that displaced workers from the least productive firms ended up in less productive activities. "In other words, rationalization of manufacturing industries may have come at the expense of inducing growth-reducing structural change" (McMillan et al. 2014: 19).

The focus of this book is the second source of productivity growth: within-firm improvements that result from firm-specific characteristics, behaviors, and strategies. Here, efficiency gains can be explained as the result of improvements in management, internal organization, strategies, or technological capabilities as reactions to market incentives.

The interaction between firm-specific factors leads to high heterogeneity in firm productivity growth over time and, consequently, firms with disparate productivity levels can coexist, even within the same sectors. ${ }^{4}$ For example, Syverson (2011) found that, within four-digit Standard Industrial Classification industries in the US manufacturing sector, the 

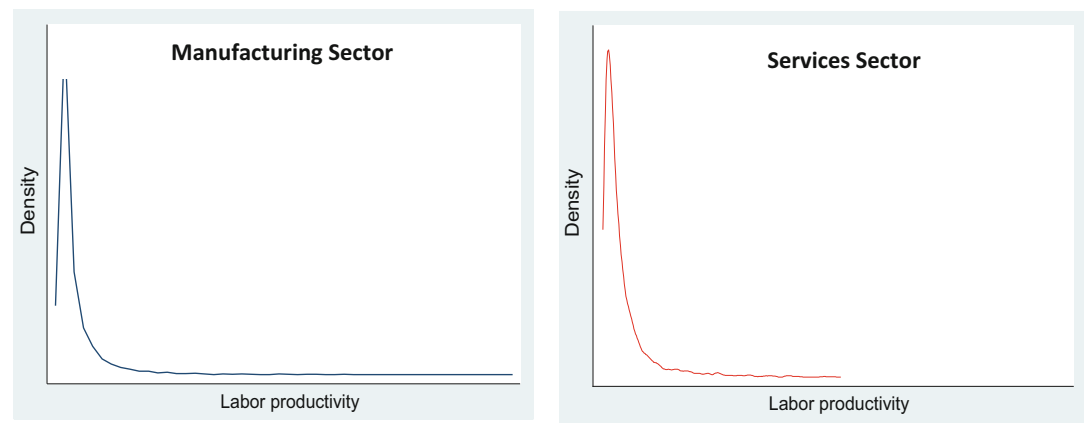

Fig. 1.3 LAC productivity distributions, 2010 (Source: Authors' elaboration using WBES data)

plant at the 90th percentile of productivity distribution had almost twice as much output as that at the 10th percentile with the same measured inputs. Even larger productivity differences were recorded in China and India, with average 90:10 TFP ratios over 5:1 (Hsieh and Klenow 2009).

Evidence from LAC confirms this situation: overall, the region is characterized by large disparities in productivity (Busso et al. 2013; Pagés 2010), with many low-productivity firms coexisting with few high-productivity firms (Lavopa 2015). Using World Bank Enterprise Survey (WBES) data for LAC, we found that the difference between the 90th and 10th percentiles of labor productivity distribution in the manufacturing sector is around 10:1. In Fig. 1.3, this trend is apparent for both the manufacturing and services sectors. Most firms are clustered at very low levels of productivity, but there are some highly productive firms. It is interesting to note that the distribution for the manufacturing sector appears to be more skewed than for the services sector, ${ }^{5}$ extending much further to the right.

Dualism is a phenomenon that is frequently encountered in developing countries, and LAC is no exception. From a theoretical point of view, dualism has been explained differently by scholars belonging to various schools of thought. On the one hand, the neoclassical approach stresses the role of market incentives and generally the macroeconomic context that induces firms to behave differently in response to different prices. Heterogeneity is the upshot of market imperfections, as a result of which inefficient firms are not forced to exit the market (e.g. Busso et al. 2013). On the other hand, evolutionary and managerial approaches refer to: the intrinsic characteristics of firms; their internal organization, routines, and practices; and specific strategies to accumulate technological capabilities, learn, and innovate (Williamson 
1973, 1985; Dosi 1988; Katz 1987; Lundvall 1992; Malerba 2002; Nelson and Winter 1982; Nelson 1991). Lall (1992) suggested, for example, that the development of firm capabilities is the result of the interplay between a "complex interaction of incentive structures with human resources, technological effort and institutional factors." Meanwhile, the dynamic capabilities approach advanced by Teece and Pisano (1994) argues that the strategic dimensions at the disposal of a firm range from managerial and organizational processes, their present position, and the paths available to them. These approaches attribute firm performance to the unique characteristics embedded within firm-specific decision-making, organization, and processes.

Foster et al. (2001) asserted that the magnitude of within-sector heterogeneity implies that firm-specific factors determine whether they achieve rapid productivity growth or suffer declines. They cited such factors as uncertainty of demand for the firm's products, managerial ability, the nature of installed capital, upgrading capabilities, location, and the diffusion of knowledge concerning new technologies. For example, uncertainty over market demand and profitability may lead firms to experiment to discover which technologies or processes best meet local market conditions (Jovanovic 1982; Ericson and A. Pakes 1989). Firm-level productivity will be affected by the success of such experimentation, and firms that have developed or acquired efficient technologies and know-how can put them to work, with immediate effects on productivity levels. Those firms still experimenting with how to most efficiently use their inputs may suffer from low productivity.

The substantial heterogeneity in firm performance provides the analytical foundation for this book, raising the question why some firms perform well while others fail. The core of the book seeks to empirically analyze the drivers of this heterogeneity, such as training, access to information and communication technologies (ICTs), international linkages, innovation, and access to finance. The heterogeneity present among firms in the region suggests the need to go beyond one-size-fits-all firm growth policies. There is an important challenge here for policymakers to devise policies that reflect the diverse nature of enterprises in LAC.

\section{Motivation for This Book}

Depending on the objective of the intervention, policies to promote enterprise development can assume very different forms. Thus, for example, policies may address the two different sets of factors that in principle affect firm performance: (i) internal factors, which at least in principle are within a business's control, and (ii) external factors, which are aspects 
of the operating environment (Syverson 2011). Among the former are a host of elements that range from internal firm characteristics, technological capabilities, organizational structure, and linkages between firms and within networks, to sector-specific factors. Among the latter are the external pressures that influence firm behavior and success, including competition, the business environment, and the institutional framework.

Over the past 20 years in LAC, priority has been given to macroeconomic reforms that typically address the external factors, preventing an efficient allocation of resources across sectors and firms by improving the business and investment climate and market functioning. However, despite their relative success, these policies alone constitute a broad brush effort to address the needs of firms. In fact, although a sound institutional and regulatory framework is a necessary condition for sustained firm growth, once these barriers are reduced, firms respond to the same framework in different ways, depending on their characteristics and strategies. Once the basic framework is set in place, achieving efficiency improvements within firms requires detailed microeconomic policies that also address the internal factors that are hindering firm-level productivity. ${ }^{6}$

Moreover, macroeconomic reforms bring about once-and-for-all static gains. Once market flexibility is achieved (or restored) and the benefits from reallocation have materialized, these gains cannot be repeated. In contrast, the advantages from within-firm efficiency improvements can be pursued continuously through efforts and investments in innovation, human capital, and increasing credit access, among others. Despite this, macroeconomic conditions are often cited as playing the most significant role in shaping firms' trajectories. While important, these factors do not adequately take into account the specific characteristics, strategy, and behavior that are equally, if not more, responsible for sustained firm development. But the priority given to macroeconomic reforms has shifted interest away from the microeconomic dimension, leading many LAC governments to place microeconomic concerns further down the policy agenda (Solimano and Soto 2006).

This book contributes to bringing the microeconomic agenda back to the forefront by presenting and critically discussing new evidence about the drivers of within-firm productivity improvement across the region. A better understanding of the factors that foster or hinder firm performance is increasingly important from the perspective of economic policies. In fact, while there is widespread consensus on appropriate macroeconomic policies, the variety and ongoing experimentation with many different microeconomic policies in the region reveals that the policy debate is far from being settled.

As a consequence, this variety is not mirrored by volume, and the size and scope of government programs aimed at directly supporting enterprise 
Table 1.2 LAC firms participating in publicly supported programs

\begin{tabular}{llll}
\hline & \multicolumn{3}{c}{ Participation in: } \\
\hline & $\begin{array}{l}\text { At least one } \\
\text { program (\%) }\end{array}$ & $\begin{array}{l}\text { Only one } \\
\text { program (\%) }\end{array}$ & $\begin{array}{l}\text { Two or more } \\
\text { programs (\%) }\end{array}$ \\
\hline All firms & 10.7 & 7.7 & 2.9 \\
Micro firms & 6.6 & 5.1 & 1.4 \\
Small firms & 9.4 & 6.6 & 2.8 \\
Medium firms & 14.4 & 10.4 & 4.0 \\
Large firms & 15.8 & 11.7 & 4.1 \\
\hline
\end{tabular}

Source: World Bank (2010)

Notes: Includes both partially or entirely government funded programs

development across LAC remain limited. For example, Brazil, the Latin American country that devotes the largest amount of resources to firm development, is reported to use $0.085 \%$ of its GDP to support small and medium-sized enterprises (SMEs). In the United States, this figure is nearly five times higher (ECLAC 2014). WBES data for LAC allow us to assess the diffusion of such instruments and the actual level of firm participation. ${ }^{7}$

Overall, approximately $10.7 \%$ of all firms report having received some type of public support over the previous three years. But large differences emerge when the responses are broken down by firm size. Only $6.6 \%$ of micro-firms and $9.4 \%$ of small firms report receiving support, compared to $14.4 \%$ of medium-sized firms and $15.8 \%$ of large firms (Table 1.2). Most firms use only one publicly funded instrument and only a small fraction participate in two or more programs $(2.9 \%)$. Again, larger firms tend to participate more often in various programs at the same time, and evidence shows that it is often important to participate in different programs to obtain their full benefits (Álvarez et al. 2012). If we consider that many public programs in the region are designed to support SMEs, the fact that large firms are using them disproportionately raises some doubts about the targeting capacity of the institutions in charge of such programs in the region.

Disaggregating firm participation by typology of intervention, innovation support turns out to be the most frequently used instrument, with $5 \%$ of firms using it. This is followed by quality certification and business development services (3.8\%) (Table 1.3). At the other extreme, only $1.5 \%$ of the firms use instruments that facilitate business alliances with suppliers and clients, and $2.1 \%$ participate in export promotion programs. In all these cases, participation rates increase with firm size. On the whole, this evidence alludes that firms in Latin America tend to participate very modestly in public programs. In the Caribbean, this number is even lower, as public support for innova- 
Table 1.3 LAC firms participating in publicly supported programs by firm size

\begin{tabular}{|c|c|c|c|c|c|}
\hline $\begin{array}{l}\text { In the last three years, firm used } \\
\text { services to: }\end{array}$ & $\begin{array}{l}\text { All } \\
\text { firms (\%) }\end{array}$ & $\begin{array}{l}\text { Micro } \\
\text { firms (\%) }\end{array}$ & $\begin{array}{l}\text { Small } \\
\text { firms }(\%)\end{array}$ & $\begin{array}{l}\text { Medium } \\
\text { firms (\%) }\end{array}$ & $\begin{array}{l}\text { Large } \\
\text { firms (\%) }\end{array}$ \\
\hline $\begin{array}{l}\text { Improve quality control/train to } \\
\text { obtain quality certification }\end{array}$ & 3.8 & 2.2 & 3.5 & 5.2 & 5.0 \\
\hline $\begin{array}{l}\text { Make business alliances with other } \\
\text { suppliers/clients }\end{array}$ & 1.5 & 1.2 & 1.6 & 1.6 & 1.9 \\
\hline Support innovation & 5.0 & 2.5 & 4.3 & 6.8 & 9.4 \\
\hline Support exports & 2.1 & 1.1 & 1.9 & 3.2 & 2.7 \\
\hline $\begin{array}{l}\text { Business development services } \\
\text { (e.g., support training or technical } \\
\text { assistance) }\end{array}$ & 2.4 & 1.5 & 2.4 & 3.2 & 2.7 \\
\hline
\end{tabular}

Source: World Bank (2010)

Notes: Includes both partially or entirely government funded programs

tion is still sporadic. According to WBES data, only $1.5 \%$ of Caribbean firms declared they had participated in innovation-related programs in 2010. This low percentage is confirmed by the data of the Productivity, Technology, and Innovation in the Caribbean (PROTEQin) Survey. In 2014, only 2.7\% of firms received public support for innovation activities.

This book uses a series of econometric models with microeconomic data primarily from the WBES to address specific research questions. The questions were chosen based on their relevance for the region and the availability of the necessary data for the analysis. Each chapter is dedicated to analyzing a different factor affecting firm productivity in LAC: innovation, ICT usage, on-the-job-training, firm age, firm size, access to credit, and international linkages. Two chapters explicitly analyze Caribbean firms.

The cross-country comparability of the results provides first-hand evidence of how these factors affect firm performance, providing readers a richer understanding of firm dynamics in LAC. The findings update understanding of the business drivers in the region, which helps inform the design and development of policies to promote business performance.

\section{Data And Methodology}

The WBES are the primary datasets used in this book. WBES data is available for over 130,000 firms in 135 countries. ${ }^{8}$ The World Bank collects survey information through face-to-face interviews with firm managers and owners regarding the business environment in their countries and 
the productivity of their firms, including questions relating to infrastructure, sales and supplies, competition, crime, finance, business development services, business-government relations, labor, and firm performance. Table 1.4 lists the countries and the number of companies surveyed in

Table 1.4 WBES: number of LAC firms surveyed

\begin{tabular}{|c|c|c|c|}
\hline & & 2006 & 2010 \\
\hline 1 & Argentina & 1063 & 1054 \\
\hline 2 & Bolivia & 613 & 362 \\
\hline 3 & Brazil & - & 1802 \\
\hline 4 & Chile & 1017 & 1033 \\
\hline 5 & Colombia & 1000 & 942 \\
\hline 6 & Costa Rica & - & 538 \\
\hline 7 & Ecuador & 658 & 366 \\
\hline 8 & El Salvador & 693 & 360 \\
\hline 9 & Guatemala & 522 & 590 \\
\hline 10 & Honduras & 436 & 360 \\
\hline 11 & Mexico & 1480 & 1480 \\
\hline 12 & Nicaragua & 478 & 336 \\
\hline 13 & Panama & 604 & 365 \\
\hline 14 & Paraguay & 613 & 361 \\
\hline 15 & Peru & 632 & 1000 \\
\hline 16 & Uruguay & 621 & 607 \\
\hline 17 & Venezuela & 500 & 320 \\
\hline Subtotal & & 10,930 & 10,074 \\
\hline 18 & Antigua and Barbuda & - & 151 \\
\hline 19 & Bahamas & - & 150 \\
\hline 20 & Barbados & - & 150 \\
\hline 21 & Belize & - & 150 \\
\hline 22 & Dominica & - & 150 \\
\hline 23 & Dominican Republic & - & 360 \\
\hline 24 & Grenada & - & 153 \\
\hline 25 & Guyana & - & 165 \\
\hline 26 & Jamaica & - & 376 \\
\hline 27 & St. Kitts \& Nevis & - & 150 \\
\hline 28 & Saint Lucia & - & 150 \\
\hline 29 & St. Vincent \& the Grenadines & - & 154 \\
\hline 30 & Suriname & - & 152 \\
\hline 31 & Trinidad and Tobago & - & 370 \\
\hline Subtotal & & - & 2781 \\
\hline Total & & 10,930 & 12,855 \\
\hline
\end{tabular}

Source: Authors' elaboration based on WBES data Note: Data for Brazil is from 2009 
2006 and 2010 that are included in the dataset. The population of the survey is consistently defined in all countries as non-agricultural, nonextracting, formal, privately owned firms. ${ }^{9}$ Both the manufacturing and services sectors are covered by the survey.

The Inter-American Development Bank (IDB) financed the 2010 WBES in 14 Caribbean countries, the first time it was conducted there. Furthermore, the IDB financed the inclusion of additional questions on key issues facing the firms of the region, including questions on innovation, business development services, and workforce training for human capital. ${ }^{10}$

The global methodology for most enterprise surveys implemented since 2006 is based on a core questionnaire with a uniform universe and methodology of implementation. The most recent survey in LAC was conducted in 2010 and, in some cases, the previous WBES conducted in Latin America in 2006 allows authors to create panel datasets for participating countries. The WBES uses stratified random sampling by location, size, and sector. This method guarantees that precise inferences can be made for each level of stratification. The standardization of enterprise surveys across all countries strengthens the level of external validity and provides a basis for comparisons across countries in the region and with other developing regions. This is especially crucial for the Caribbean, which had very little comparable firm-level data available before the 2010 surveys.

Despite the benefits of enterprise surveys, there are limitations that should be addressed. First and foremost, the surveys are administered to a representative sample of firms in the non-agricultural, formal, private economy. Consequently, by definition, the informal sector is excluded from the analysis. The effect of this limitation varies because the size of the informal economy differs by country. In countries like Paraguay and Nicaragua, the informal sector accounts for an estimated $70 \%$ of total GDP; in Caribbean economies like the Bahamas, Grenada, St. Kitts \& Nevis, Trinidad and Tobago, and Barbados, the informal share is estimated to hover below $25 \%$ of GDP (Vuletin 2008). Regardless of the country, the exclusion of informal firms requires a cautious interpretation of the empirical results.

Another data limitation is the relatively low representation of services firms in the survey population. This is unfortunate given that services make up $60 \%$ of employment in the region. While both the manufacturing and services sectors are included, services firms were excluded from some of the key modules of the questionnaire, such as the innovation module in the 2010 survey and the labor module in the 2006 survey. When the data 
allow, the authors use observations from both sectors. However, this is not possible in those chapters where services firms are excluded from questionnaire modules, creating an unintended focus on manufacturing firms.

Other limitations of the data create some methodological issues that are addressed in a uniform way throughout the book. The first methodological decision was made in response to the low response rates in certain countries. The low number of observations for some of the key variables prohibits analysis at a country level. Therefore, the authors aggregate countries together for the empirical analyses, allowing for interpretations at a regional level only. All authors use country-level dummies to take into account cross-country heterogeneity.

The second issue is the conversion of financial variables. The WBES follow the World Bank methodology that first converts local currency variables to US dollars using market exchange rates and then subsequently deflates them to the reference year, 2009. An alternative methodology would be to use a measure of purchasing power parity (PPP) or the rate at which the currency of one country would have to be converted into that of another country to buy the same amount of goods and services in each country. Free of price and exchange rate distortions, the PPP methodology is often considered a better measure when making crosscountry comparisons, especially for developing or emerging markets. ${ }^{11}$ Despite these limitations, we follow the World Bank methodology, using market exchange rates for our analysis, for a number of reasons. First, to make accurate PPP comparisons, ideally, inputs and outputs need to be converted separately using different PPP converters; however, this was not feasible because of data limitations. Second, the greatest distortions between the two measures tend to occur when emerging country figures are converted into US dollars at market exchange rates and used for comparisons with developed countries. The LAC WBES are all developing economies within the same region, so we expected the distortions to be smaller than those found between LAC and other developing or advanced economies. Last, as already mentioned, country fixed effects are used in the regressions in all chapters to partly capture any persistent discrepancies between PPPs and exchange rates.

Another methodological issue is the decision about which measures of performance to use. Sales, employment, and productivity growth are just a few of the methods available to gauge firm performance. With the macroeconomic evidence of low productivity growth well established, this book uses firm-level productivity as the primary measurement of 
firm performance. It relies on labor productivity, calculated as sales per employee, as a measure of firm efficiency and performance. Where the data allows, authors also estimate the TFP. Both measures aim to proxy firm efficiency in using production inputs, thereby providing a basis to compare performance across firms.

Finally, while the main dataset is the WBES, the authors also use additional data sources to create another level of analysis when possible. Two relatively new micro-datasets are particularly interesting. Chapter 5 uses the IDB-financed Survey of Productivity and Human Resources in Establishments (Encuesta sobre Productividad y Formación de Recursos Humanos en Establecimientos, or EPFE), which includes detailed questions about on-the-job training that are not included in the WBES or other traditional business surveys. ${ }^{12}$ For the Caribbean region, Chap. 7 uses the Productivity, Technology, and Innovation in the Caribbean (PROTEQin) Survey in tandem with the 2010 WBES. The PROTEQin expands the scope of WBES and incorporates more detailed questions related to labor, technology and innovation, commercial victimization, and productivity for 727 Caribbean firms. ${ }^{13}$ Furthermore, Chap. 9 uses the new Organisation for Economic Co-operation and Development (OECD) and World Trade Organization (WTO) Trade in Value Added (TiVA) database.

\section{Overview OF THE BOOK}

The first three chapters of this book focus on innovation dynamics in LAC firms. They are followed by chapters dealing with specific factors affecting enterprise performance, such as on-the-job training, performance of young firms, access to credit, and international linkages. Two of the eight chapters-Chaps. 3 and 7-focus specifically on Caribbean economies, with new data sources for many of these small economies allowing for comparisons with larger mainland economies in Latin America.

\section{Innovation Dynamics and Productivity: Evidence FOR LATIN AMERICA}

Chapter 2, co-authored by Gustavo Crespi, Ezequiel Tacsir, and Fernando Vargas, focuses on the key relationships between innovation efforts, innovation outputs, and productivity. This chapter analyzes the links between firm characteristics and decisions about investments in innovation, between investment in innovation and innovative performance, 
and between innovative performance and economic performance. It also examines the role of spillovers between firms. All the empirical analyses use a cross-sectional dataset for 17 countries in Latin America, constructed from the 2010 round of WBES.

In a review of the firm-level literature on innovation, the chapter finds that, in general, innovation leads to more efficient use of resources and sustainable competitive advantage. Investment in research and development (R\&D) tends to increase absorptive capacity, assimilation of knowledge, and catch up. Innovation and application of new ideas lead to the emergence of new sectors (structural change). In turn, changes in the production structure result in more complex chains of production, specialization, productivity growth, and a gradual expansion of more knowledge-intensive activities. At the macro-level, R\&D, innovation, productivity growth, and per capita growth in GDP can reinforce each other in virtuous (or vicious) cycles.

The review also identifies some important differences between the findings of studies in Europe and studies in developing countries. First and foremost, the productivity gaps between innovative and non-innovative firms are much larger in developing $(70 \%)$ than in advanced economies $(20 \%)$. The productivity gaps highlight the shortcomings of ineffective innovation systems, where knowledge does not flow sufficiently easily from actor to actor. But they also indicate substantial potential for improvement through public policy measures intended to promote investment in innovation by lagging firms as well as more effective knowledge flow and improved conditions for knowledge absorption. A second important difference is that the strong links between innovation investment and innovation performance and between innovation performance and economic performance found in Europe are more ambiguous in Latin America, where the results of different studies have been inconclusive. According to the authors, the heterogeneity of findings may have to do with the very different circumstances in developing countries and emerging economies. Many firms are far from the technological frontier, incentives to invest in innovation are absent or weak, and it may take longer for effects to materialize (which makes the relationships more difficult to measure in a cross-section framework). Also, many innovations consist of incremental changes based on imitation and technology transfer, with little impact on competitiveness in international markets.

The authors build on a model first developed by Crépon et al. (1998), referred to as the Crépon-Duguet-Mairesse (CDM) model, that includes three steps. In the first step, the analysis focuses on the decision to spend 
on innovation. Next, an innovation function is estimated, relating subjective indicators of product and process innovation to innovation expenditures and other explanatory variables. Finally, the analysis focuses on the key relationship between innovation performance and labor productivity. This relationship is assessed in the context of a standard Cobb-Douglas production function with constant returns to scale, where innovation performance is added to capital and labor inputs, allowing the returns on innovation to be estimated.

In the various regression equations, five groups of variables are distinguished: (1) performance variables (e.g. labor productivity, employment, investment, and R\&D); (2) innovation variables (e.g. product innovation, process innovation, innovative sales, and intellectual property rights); (3) firm capabilities (e.g. firm age, foreign ownership, human capital, knowledge stocks, and diversification); (4) degree of access to external knowledge (e.g. cooperation with other firms, urban location, use of licenses, and broadband access); and (5) market conditions (e.g. degree of competition and whether or not a firm exports to international markets). The variables on market conditions relate to policy, which includes the percentage of firms receiving public support for innovation activities by sector and country. Many of the variables described here are also used in subsequent chapters of this book.

The following summarizes the most striking findings in this chapter. The decision to invest in innovation $(\mathrm{R} \& \mathrm{D})$ is strongly correlated with firm size and firm capabilities and is significantly and positively affected by public support. The intensity (amount) of investment is positively affected by firm capabilities (human capital and previous knowledge stock), access to external knowledge via licenses and connections, and public support. Surprisingly, the intensity of competition has no effect on the decision to invest and there are even significant negative effects of foreign control. Multinationals do not seem to invest in technology development locally.

What is the effect of R\&D investment on innovative performance? Here the answer is straightforward and positive. A $10 \%$ increase in R\&D spending results in a $1.7 \%$ increase in the probability of innovating. Most of the relationship between expenditure and innovation is through product innovation rather than process innovation. Some firm capabilities, such as size, diversification, and fixed investment, are important determinants of innovation outputs beyond their influence on R\&D investment. Again there are some interesting results related to factors that negatively affect innovation. There are no significant effects on the stock of knowledge, 
but human capital is negatively correlated with innovative performance, and being a multinational has negative or non-significant effects. The effect of human capital is puzzling. Perhaps firms do not really require highly skilled workers because the product innovations are not very complex. But this still begs the question as to why the effect is negative.

One of the chapter's most powerful findings is that the effects of innovation on productivity are positive and large. Total factor productivity of innovative firms is $50 \%$ higher than that of non-innovative firms. In this respect, our research findings differ from the ambiguous findings for Latin America discussed in the literature review and the relationships are unambiguous.

The last two questions addressed in the chapter have to do with spillovers and heterogeneity. The authors conclude that there are positive and significant spillover relationships between R\&D performed by other firms in the same sector and country, and a firm's economic performance. Unfortunately, a cross-sectional analysis does not provide enough information to discuss clearly the magnitude and importance of these spillover effects. In the final part of the chapter, the authors present some very interesting and quite novel findings about differences (heterogeneity) in the relationships between innovation performance and productivity across firms. On average, productivity increases when innovation occurs, shifting the whole productivity distribution to the right, but not equally. At the upper end of the productivity distribution, the increase in productivity is much higher than at the lower end.

The authors reflect on the policy implications of this heterogeneity. They argue that the lower returns on innovation in low-productivity firms suggest that the constraints on productivity improvement are not primarily financial since these firms are indeed innovating. The authors believe the lower returns have to do with some firm characteristics, such as the lack of complementary assets or the lack of appropriability of innovation. The importance of access to finance is discussed again in Chap. 8.

\section{Innovative Activity in the Caribbean: Drivers, Benefits, and OBstacles}

In Chap. 3, Preeya Mohan, Eric Strobl, and Patrick Watson examine the impact of innovation on firm productivity in the Caribbean, discussing questions and models similar to those in Chap. 2. So far, not much is known about firm performance in Caribbean countries and even less about their innovative behavior. This is mainly due to a lack of reliable 
data for the region, which is usually lumped together with Latin America. The availability of the 2010 WBES covering 14 Caribbean countries (and 2771 firms) for the first time makes it possible to address these issues empirically. Along similar lines as Chap. 2, the authors analyze the decision to invest in innovation, the impact of such investment on technological innovation (knowledge production), and the relationship between innovation and productivity. The few studies available for the Caribbean tend to use R\&D expenditures as their measure of innovative activity and find that both innovation and productivity are low. However, excessive emphasis on R\&D expenditures may underestimate the role of other forms of innovation that may be more important in small island developing states, where the cost of R\&D is high and firms are too far from the technological frontier to have strong incentives to invest in $R \& D$. This chapter uses a broader concept of innovation investment. In line with results obtained for many Latin American countries (Crespi and Zúñiga 2012; Chap. 2 of this book), innovative firms tend to be more productive than non-innovative firms; innovation matters for firm productivity performance.

The chapter starts with a descriptive analysis which reveals that in the manufacturing sector, the only one for which innovation data is available, innovative firms in the Caribbean tend to be medium-sized, domestic enterprises, half of which export a product. Moreover, there appear to be systematic differences in productivity between innovative and noninnovative firms (i.e. firms that do not spend any funds on R\&D and/ or technological innovation activities). The results are robust to different non- and semi-parametric specifications of the estimates and to different measures of productivity (i.e. labor productivity and TFP). However, when analyzing the counterfactual- that is isolating the innovation behavior from other firm characteristics - the study suggests that differences in performance between the innovating and non-innovating firms are due more to underlying firm characteristics such as export status, foreign ownership, patent possession, government support, and size than to being or not being innovative.

The authors search for causality in the relationship between innovative performance and productivity. Firm innovation involves any action that aims to increase the firm's knowledge, including R\&D expenditures, but also efforts to acquire external knowledge, such as expenditures on product design, marketing, staff training, new machinery, and patents and other trademark licensing. 
The econometric estimates are run on a pooled dataset across countries and follow the CDM three-stage approach described above and in Chap. 2. The results show that firms that export and are larger are more likely to invest in innovation, while having patent protection or foreign ownership does not significantly predict the decision to invest in innovation. The positive effect of size and export status on the decision to innovate is not surprising. The lack of significance of the foreign ownership variable appears to signal that foreign firms develop their technologies abroad and only use Caribbean countries as an outlet for their products. This is a frequent finding in studies of foreign direct investment (FDI) in developing countries.

Public financial support is not a significant predictor of the intensity of investing in innovation, suggesting that, in contrast to mainland Latin America, public funds do not effectively promote innovation in the Caribbean. Having patents or cooperating with other firms also do not appear to encourage investment, perhaps indicating limited inter-firm knowledge spillover. Other results for the Caribbean countries are similar to those obtained for Latin America, but generally with larger effects. Caribbean firms are more likely to introduce product or process innovation if they spend more on innovation: the probability of innovation increases by $56 \%$ per unit increase in the log of innovation expenditure per employee.

The authors also estimate the causal impact of innovation on productivity in an econometric framework. The results suggest that product and process innovation increase productivity in the Caribbean with an estimated elasticity that is larger than for Latin America. Small firm size appears to be less of an obstacle for innovation to improve productivity.

\section{ICT, Innovation, and Productivity: Evidence} from Firms in Latin American ANd the CARIBbean

In Chap. 4, Matteo Grazzi and Juan Jung single out ICTs as one of the important factors influencing firm performance. They analyze the determinants of broadband adoption in a large sample of LAC countries, and study their relationship with innovation and productivity.

Recently the economic literature has progressively recognized the role of ICTs as a key driver of economic growth. At the firm level, adopting ICTs can influence performance in various ways, such as faster communication and information processing, easier internal coordination, 
lower capital requirements, and better communication with suppliers and customers. However, in the absence of complementary investments in, for example, human capital or organizational improvements, simple diffusion of ICTs may not be sufficient to fully exploit their benefits. This chapter adds to the still limited evidence regarding these relationships for developing countries.

In the first part of the chapter, the authors empirically test the validity of various models of ICT diffusion, both at the inter-firm and the intrafirm levels. The latter part of the analysis is original because the processes by which ICTs diffuse within organizations have been little studied. In particular, the authors test propositions from rank and epidemic models. Rank models focus on the scores of firms on various characteristics, such as age, size, or human capital. Epidemic models predict that the greater the number of firms adopting broadband in a sector or a country, the greater the chance that a given firm will adopt broadband. The authors apply a probit model, and then a bivariate probit model, to control for multicollinearity. The results are robust to all the specifications and consistent with previous analyses in the literature. Firm size appears to affect the probability of broadband adoption, while the quality of human capital (percentage of workers with at least a bachelor's degree) and firm age affect adoption positively. These results hold for the entire sample, as well as separately for firms in the manufacturing and services sectors. Openness to foreign markets through participation in foreign trade-but not foreign ownershipincreases the probability of broadband adoption.

The expected epidemic effects are confirmed. In non-technical language, firms operating in countries and sectors with larger shares of firms using ICTs have a higher probability of adopting them. Moreover, firms located in urban agglomerations with more than one million inhabitants are also more likely to adopt broadband.

To tackle the important issue of factors affecting ICT diffusion from firm to firm and within a firm itself, the authors construct an indicator based on the availability of broadband in a firm and the number of activities performed with it. The results show a similar pattern to those for interfirm diffusion, with a significant positive effect of firm size. It appears, however, that there is a threshold, above which size no longer matters for intra-firm diffusion of ICTs. This threshold turns out to be lower for manufacturing firms than for services firms. Location in an urban agglomeration positively influences the decision to adopt broadband by the firm, but not how extensively it is used within the firm. 
In the second part of the chapter, the authors empirically examine the effects of ICT adoption on innovation performance and labor productivity. The analysis shows that the impact of ICTs on innovation may be conditioned by several characteristics internal to the firm as well as external, such as the linkages with strong external organizations and network externalities. The authors show that using broadband is positively and significantly correlated with the probability of product and process innovation in firms. However, when they single out the different possible uses that a firm can make of broadband, the results begin to differ. First, using the internet to perform research is positively and significantly related to innovation, but no other uses are related to innovation. Second, the combined use of broadband for different activities matters and has a significant impact on innovation on top of the effects of using the internet for research. This is to say that simple access to ICTs is not enough to foster firm innovation. Technology needs to be used adequately to exploit its full potential. In addition, other variables are associated with a higher probability of innovation, such as firm size, human capital, and openness to export markets. This latter result confirms the evidence obtained in different contexts by Crespi et al. (Chap. 2) and Montalbano et al. (Chap. 9).

Using a Cobb-Douglas production function, the authors show that using broadband also has a positive effect on labor productivity, and that this result is robust when controlling for endogeneity. When testing for the effect of the different kinds of internet uses, research loses its significance, perhaps due to the time lags between investments in broadband and the related research and the ensuing productivity effects. However, the simultaneous use of the internet for various activities and overall broadband adoption retain their positive influence on productivity. The lesson to be derived from this chapter is that ICT adoption and diffusion should receive special attention within the broader perspective of innovation and innovation policy.

\section{On-THE-Job-Training In Latin America AND the CARIBbean: ReCEnt Evidence}

In Chap. 5, Carolina González-Velosa, David Rosas, and Roberto Flores focus on an important but neglected aspect of human capital formation: on-the-job training. The secondary literature indicates that up to a quarter of human capital is obtained after formal schooling has ended 
(Heckman et al. 1998). Also, the type of training provided on the job may be more relevant to the production process than the skills learned in formal education.

The chapter opens with a brief review of theories of on-the-job training. Labor market theory assumes that, under perfect market conditions, the benefits of general training will accrue to the worker. As generalized training increases the productivity of workers, they will be able to increase their wages or leave the firm to work elsewhere. Therefore firms have no incentive to finance generalized training. Firm-specific training may increase a worker's productivity, but it does not increase the worker's employability. The benefits of productivity increases accrue to the firm, which thus has an incentive to invest in such training. The authors also provide a brief but useful overview of five barriers to investment in on-the-job training. The first is the lack of appropriability: if the firm cannot capture the benefits of training, it will have no incentive to invest in on-the-job training. The second is imperfect information about the advantages of training. The third is credit constraints. These three barriers affect the supply side. The last two barriers affect the demand side. If firms are facing limits to adopting skill-intensive technologies or modern managerial practices, there may simply be no demand for skilled labor and accordingly little incentive to invest in on-the-job training.

The chapter draws on two different data sources. The first is the WBES, which is the common source for all chapters of this book. The second is a Latin America-specific survey of human capital formation, the EPFE, which provides more detailed information about on-the-job training in five countries (the Bahamas, Colombia, Honduras, Panama, and Uruguay). The authors use a panel dataset of the WBES for 11 countries that participated in both the 2006 and 2010 waves of the survey for the regression analysis, though only for manufacturing.

Compared to other developing regions, firms in the 26 Latin American countries for which the authors have data offer quite a lot of on-the-job training, ranging from $26 \%$ of the firms in Jamaica to $60 \%$ in El Salvador (incidence of training). In the firms that offer training, the proportion of workers trained (intensity of training) is also quite high, ranging from $38 \%$ in Uruguay to $79 \%$ in Colombia. Skilled workers receive much more training than unskilled workers, so existing skill gaps tend to be amplified. Training is specific and does not involve general socio-emotional or behavioral skills.

The employers pay most of the training-related costs and provide most of the training themselves. Governments provide some training 
opportunities, but these are not used much, not even by small firms. When firms turn to external providers, they choose private companies. The authors speculate on the reasons for the unimportance of public funding and provision, and argue that this could be due to lack of coverage in rolling out programs or irrelevance of their content.

However, there are clear differences between more innovative and less innovative firms: more innovative firms (i.e. higher R\&D expenditures, improved processes, ISO certificates, and new products) often decide to train their workers. The surveys provide some interesting information about the reasons why many firms do not choose to train their workers. The main reason is that they do not see it as necessary. Skills are not perceived as a major constraint to operations. This is consistent with the theoretical argument that absence of innovative skill-intensive technologies limits the demand for more training of skilled labor. Many firms find their workers to be adequately trained. The policy implication is that it does not make much sense to subsidize on-the-job training in the absence of demand.

The final section of the chapter provides estimates of the effects of on-the-job training on TFP. When country fixed effects and control variables are added, the effects of training are not significant in general. However, in large firms (with more than 100 workers) there is a clear, significant, and positive effect of training: a $1 \%$ increase in the proportion of trained employees would raise productivity by $0.7 \%$.

The authors emphasize that the findings of this study should be treated with caution. However, what comes out rather clearly is that many firms do not see training their employees as a high priority. Only when firms become more innovative does demand for training emerge. As Crespi et al. show in Chap. 2, public policies have a significant effect on firms' investments in innovation. Thus, rather than subsidizing on-the-job training directly, public policy should promote increased innovativeness of firms. Indirectly this would result in greater demand for skilled labor and on-the-job training.

\section{Business Performance in Young LATIN AMERICAN Firms}

In the Schumpeterian literature, there are periods of economic development in which dynamic small firms are the agents of innovation and economic development. In other periods, referred to as Schumpeter II 
regimes, mature incumbent firms are much more important. In Chap. 6, Hugo Kantis, Juan Federico, Pablo Angelelli, and Sabrina Ibarra García discuss the performance and characteristics of small, young manufacturing firms in Latin America. While most of the literature on young firms focuses on startups, the authors examine the potential of young firms that have survived four years but are still younger than ten years. They study whether such young firms are a potential source of innovation, rejuvenation, and renewal of the economy. The analysis is based on a sample of 1074 young firms in 12 Latin American countries drawn from the WBES.

In the sample, almost $20 \%$ of all firms are young (i.e. four to ten years old), and in several countries young firms have a larger presence in knowledge-based sectors than mature companies (e.g. technology services and engineering-intensive manufacturing). They contribute to diversification of regional industrial structures by embarking on new activities. The entrepreneurs have previous experience as employees, often in managerial positions in mature companies, and only $3 \%$ of the entrepreneurs were previously unemployed. So there are few 'necessity entrepreneurs' in this category, although informal micro-enterprises are excluded from the surveys used in this book, and that is where survival entrepreneurship is generally found. Half of the young firms employ between 10 and 49 workers. They are mainly focused on domestic markets and only 16\% export. Quite a few firms performed R\&D (43\%), a percentage similar to that for mature firms, and introduced new products or processes in the period analyzed. In terms of their growth performance, whether measured as sales growth or employment growth, young firms are quite dynamic. Most start as micro-enterprises with no more than five employees, but they can survive, grow, and develop into SMEs. Of course most startup failures occur in the first four years, and the firms in the sample are those that survived the socalled 'valley of death.' Sales growth slows down in the last two years but is still fairly high. The authors conclude that three-quarters of the young firms tend to achieve sales growth, $40 \%$ of them growing very rapidly at more than $20 \%$ per annum. One interesting feature of the high-growth SME segment is their stronger specialization in knowledge-intensive sectors, such as engineering-intensive manufacturing or technology sectors ( $29 \%$ of young firms and $21 \%$ of mature firms), suggesting their role is propelling a structural transformation.

Though young firms tend to have dynamic growth performance, their average labor productivity in 2009 was more than $20 \%$ lower than that of mature firms. However, young firms tended to catch up with mature 
firms, especially in services, during the short period studied (2007-2009) and their relative productivity increased from $72.0 \%$ in 2007 to $79.2 \%$ in 2009. High-growth SMEs show the biggest increase in productivity levels, especially in the manufacturing sector where young, growing SMEs outperform mature firms.

In the last section of the chapter, the authors analyze the determinants of sales growth, employment growth, productivity levels, productivity growth, and profitability using Ordinary Least Square regressions. The econometric analysis is restricted to manufacturing firms. The results are inconclusive, but some interesting findings stand out. There appears to be a positive and statistically significant relationship between the high-growth status of young manufacturing firms and their productivity levels, on average $32 \%$ higher.

Regulatory obstacles (e.g. tax rates, labor regulations, licenses, and permits) have a significant negative effect on sales growth. Financial constraints (lack of access to finance) have a negative impact on both employment growth and levels of productivity. Technical assistance (use of external technical services) has a significant and positive effect on sales growth and, with workforce training, on productivity levels. Though young firms are not less innovative than mature firms, the positive effects of innovation on productivity performance discussed in Chap. 2 do not seem to hold for young firms.

The general conclusion from this chapter is that, even though we do not know much about the determinants of performance for young firms, they are dynamic compared to mature firms, and therefore deserve special attention from researchers and policymakers. Their contribution to macroeconomic development should be studied in more detail.

\section{Different Obstacles for Different Productivity Levels? An Analysis of Caribbean Firms}

In Chap. 7, Alison Cathles and Siobhan Pangerl examine the implications of small country size in the island economies of the Caribbean. The chapter uses new firm-level data from the WBES and the PROTEQin Survey to better understand Caribbean firm dynamics and the differences among Caribbean countries.

The firms in the region tend to be micro or small, concentrated in the services sector, mature, and non-exporters. Comparing firms in different Caribbean countries, various differences emerge: smaller countries 
typically have a higher percentage of micro and small firms, the concentration in the services sector varies from 50 to $84 \%$, and there are considerable differences in ICT penetration rates.

Then, the authors deepen the analysis and discuss the characteristics of human capital in Caribbean firms from two perspectives: entrepreneurs and workforce. Considering both firm owners and managers to be entrepreneurs, the authors find that previous experience varies widely throughout the region. In general, entrepreneurs tend to have previously been employed (either in managerial or non-managerial positions), but in some countries there is a significant percentage that transitioned directly from unemployment to being a top manager. This finding is consistent with the high percentage of firms in those countries that report that the business was started because of a lack of better employment opportunities. Moreover, the authors show that few Caribbean firms are created to introduce a new idea or product into the market. Rather they tend to replicate, imitate, or differentiate products or services that already exist. Thus, the capacity of a firm to absorb external technology and knowledge is key to good performance. But this capacity is strictly related to the availability of a sufficiently skilled workforce, a major concern in the region. In fact, over $35 \%$ of Caribbean firms report having unfilled vacancies, and the lack of an adequately educated workforce is one of the obstacles to firm operations most frequently mentioned in the surveys.

The next section of the chapter focuses on productivity. Larger, older, exporting, ICT-using, and foreign-owned firms are found to be more productive in the manufacturing and services sectors. As regards human capital, firms with more experienced managers on average show higher productivity, as do firms with a higher proportion of employees with at least a bachelor's degree.

Finally, the authors investigate the perception of Caribbean enterprises with respect to the main obstacles affecting their operations. In addition to scarcity of adequately educated workers, difficulties in getting access to finance, inefficient electricity, and high tax rates are consistently cited as the most relevant obstacles. Nevertheless, when the firms are classified by their productivity levels, by dividing the sample into labor productivity quintiles, it is clear that the perception about most relevant obstacles can change, possibly because more productive firms have different needs.

The descriptive analysis is complemented by an econometric estimation of the determinants of firm productivity in the region. Using quantile regression techniques, the authors differentiate the effect of various firm 
characteristics and perceived obstacles, depending on where the firms lie in the distribution of labor productivity. As for access to finance, the firms that report this as the main obstacle to their operations underperform only when they belong to either the lowest decile or the upper half of the productivity distribution. For firms in other parts of the distribution, there are no significant differences in performance between enterprises reporting access to finance as their main obstacle and enterprises not mentioning access to finance. This is an interesting result, as it opens the possibility for Caribbean policymakers to maximize the effectiveness of their interventions by designing different policies depending on the types of firms being targeted.

Credit Access in Latin American Enterprises One of the possible determinants of both innovation and productivity improvement is access to credit. In Chap. 8, Andrea Presbitero and Roberta Rabellotti single out this factor for special attention. Firms often mention lack of access to bank credit as one of the main constraints on growth, productivity, innovation, and export capacity, particularly regarding SMEs (Ayyagari et al. 2012).

Recent empirical studies find that the lack of adequate access to finance represents an important constraint to productivity growth at the firm level. Previous literature finds that the extent to which firms are financially constrained depends on micro-factors, as well as institutional frameworks and credit market structures. For example, firms that are more informationally opaque - it is harder to acquire reliable information about them-are more likely to be financially constrained. The degree of market concentration, the proximity between lenders and borrowers, the level of foreign bank penetration, the institutional setting, and the structure of the credit market all affect firms' access to credit. However, these results for advanced economies are not easily applicable to emerging and developing countries because of significant differences in firm size distributions and characteristics as well as in institutional, macroeconomic, and financial structures. This chapter aims to uncover the possible heterogeneities in financing constraints across firms and countries in LAC and to explain them according to differences in firm characteristics, as well as countrylevel institutional, macroeconomic, and financial settings.

The empirical analysis uses comprehensive data from the WBES for 31 countries in LAC and is matched with macroeconomic data on the credit market structure and the institutional settings in different countries. The data shows that, since 2006, there has been a general deepening of the domestic financial systems in LAC. However, there are still significant gaps 
and, in general, there has not been a convergence toward the measured levels of financial development observed in more developed countries. The region is characterized by a heavy presence of foreign banks, concentrated credit markets, and considerable variation in credit registry practices (in 2010, about half of all LAC countries had credit registries).

In the WBES, the use of bank credit is shown to be extremely limited for micro and young firms, while it is the second source of finance for large firms. More productive firms rely less on internal funding for working capital and tend to use more bank and trade credit. Access to bank credit is quite heterogeneous between countries. In Mexico, less than $30 \%$ of firms have an overdraft, a line of credit, or a loan, whereas in Brazil, Colombia, and Chile, the numbers are much higher and Argentinean firms are somewhere in the middle.

The empirical models measure demand for credit and credit availability across firms and countries on four binary indicators: loan demand, loan denial, constrained, and discouraged. Larger and older firms, as well as exporters, are more likely to demand bank credit. This pattern is reflected in a higher share of discouraged borrowers in smaller, younger, and more domestically oriented companies. As a result, these firms are more likely to be financially constrained. Foreign-owned firms are less likely to apply for bank credit than domestically oriented firms, but there is no robust evidence that they are more likely to be financially constrained.

Labor productivity is found to be statistically associated with better access to credit. High-productivity firms are significantly more likely to demand credit and less likely to be financially constrained than lowproductivity firms. This finding suggests the presence of a financing constraint trap for low-productivity firms, as they are most likely to be financially constrained but do not have the resources to invest to improve their performance.

In terms of external characteristics, bank penetration, as measured by the number of branches per capita, is significantly correlated with a lower probability that borrowers are financially constrained and discouraged. This finding is consistent with the hypothesis that physical proximity to credit markets helps mitigate informational asymmetries between lenders and borrowers. When the authors control for degree of competition, a larger number of branches per capita reduces the average distance between firms and banks, which in turn reduces informational asymmetries and facilitates banks' screening and monitoring activities. Interestingly, the authors find that the presence of foreign banks can have both positive and 
negative effects on firms' financing constraints. Foreign bank penetration has a negative effect on access to credit in less developed and more concentrated markets, while it has a positive influence in more competitive and financially developed markets.

The results underline the importance of improving the functioning of domestic market structures. Policies to increase the degree of bank penetration and competition in financial markets can positively impact firms' access to credit and their productivity. Given this, the large heterogeneity in LAC financial markets provides ample opportunities for policies to increase productivity in countries across the region.

\section{International Linkages, Value-Added Trade, ANd the Productivity of LAC Firms}

The relationship between international linkages and firm productivity in LAC is an important topic. Though participation in international trade and the presence of inward foreign investment are often assumed to be a potential source of positive learning effects for local firms, there is no consensus in the literature on the existence of such effects and the factors that influence them. Moreover, the direction of causality between openness to trade and investment and firm performance is theoretically contested, while the empirical evidence is mixed.

Chapter 9, by Pierluigi Montalbano, Silvia Nenci, and Carlo Pietrobelli, contributes to this debate by investigating the issue in LAC, with a particular focus on the relationship between participation in global value chains (GVCs) and productivity. The authors claim that the increasing international fragmentation of production has made it necessary to rethink the concept of international trade, evaluating the value added in each step of production. This approach requires data beyond the standard trade statistics. So, the chapter uses the new OECD-WTO TiVA database to obtain indicators regarding the decomposition of the value added embodied in national exports and the participation and position of country industries in GVCs. Combining these indicators with the enterprise survey data, the authors provide a descriptive analysis of firms' international linkages in Argentina, Brazil, Chile, and Mexico, the only four LAC countries for which TiVA and WBES data are both available for the same fiscal year.

As for participation in GVCs, the picture differs from country to country. While it is substantial for Chile and to a lesser extent for Mexico, the involvement of Argentinean and Brazilian firms is limited. This can 
be explained by both a size effect-larger economies tend to be more self-sufficient in producing inputs for exports-and by different patterns of specialization: a relative specialization in manufacturing results in a higher degree of global participation than specialization in other sectors. Compared to their international counterparts, the Latin American countries under consideration are generally located upstream in GVCs (Brazil shows the highest GVC position in international comparison), with the relevant exception being Mexico. Again, differences are related to the countries' production structures.

Using a pooled dataset for the entire sample of LAC countries included in the enterprise surveys, the authors perform a three-step empirical exercise to investigate whether LAC firms characterized by stronger international linkages (in terms of trade and FDI) have higher productivity in comparison with LAC firms with weaker linkages. First, they perform a preliminary, static analysis of firm productivity premia for exporting and foreign-owned firms. As expected, there is a positive relationship between international linkages and firm productivity, in line with the theoretical predictions that low-productivity firms operate in the domestic market while firms with higher productivity export and compete in international markets.

Second, this result is tested using a Cobb-Douglas production function with labor, capital, and knowledge augmented by international linkages. As before, exporters and/or foreign-owned firms, on average and ceteris paribus, have higher productivity, with some heterogeneity by firm size. Third, in order to check for endogeneity bias, the authors perform instrumental variable (IV-2SLS) and control function (CF) estimations, confirming the existence of a causal relationship between exports and firm productivity.

Finally, the chapter focuses on the effect of GVC involvement (both participation and position) on firm productivity. This analysis is performed at the industry level, assuming firm performance in value added is heterogeneous across industries but homogeneous within them. Because of data availability, the sample is restricted to exporting firms from the four LAC countries for which TiVA data are available (Argentina, Brazil, Chile, and Mexico). The results show that there is no additional productivity effect in clustering firms by trade in value added, once the impact of gross exports is controlled for. This suggests that the effect of participation in international trade as such is more important than its specific value content. However, the position of the industry in the GVC is found to be important. Being upstream in a GVC has a positive impact on firm productivity performance. Thus resource production or processing is more productive than downstream assembly. 
In conclusion, the results presented in the chapter support the hypothesis of a positive causal relationship between international activities and firm performance at the firm level in LAC. Moreover, this study constitutes a first attempt to explore the effects of participation in a GVC on industry performance in the region. Industries positioned more upstream in GVCs are more productive than more downstream ones. This is an interesting finding that confirms the impossibility of considering trade as a unitary concept and the necessity to differentiate it by its value added.

\section{Key Questions}

Five groups of questions have guided the authors of the chapters of this book.

1. How important is innovation for firm-level performance? How innovative are firms in LAC? What are the empirical and theoretical connections between investment in innovation and innovation performance on the one hand, and innovation performance and productivity levels and productivity growth on the other? To what extent do firms profit from each other's knowledge and innovative activities?

2. How do differences in firm characteristics affect their innovation and productivity performance? What are the specific effects of factors such as broadband access, on-the-job training, and access to credit on firm performance? What are the differences between Latin American firms and Caribbean firms in terms of innovation and productivity dynamics? What are the implications of firm heterogeneity for economic policy design?

3. What role do young firms play in the dynamics of innovation, employment creation, and productivity growth? How do young firms differ from more mature firms?

4. How does globalization affect innovation and productivity in LAC firms? What is the role of FDI, participation in exports, and positions in GVCs on innovation and productivity growth?

5. What are the effects of public support for investment in innovation, and public policies to improve access to finance, human capital, and on-the-job training? What can we learn about the effects of policy through a better understanding of firm and country heterogeneity? 
In the subsequent chapters these questions are discussed and analyzed in detail. In the concluding chapter, we revisit the questions and reflect on the lessons and policy implications of these studies.

\section{Notes}

1. East Asian countries considered in this analysis are Hong Kong, Malaysia, Singapore, South Korea, and Thailand (World Development Indicators, accessed November 2014).

2. Productivity is measured in multiple ways, with labor productivity and TFP being two of the most common measures. Labor productivity is a simple calculation of output (or value added) per hour, whereas TFP is slightly more complex and calculated by measuring the portion of output not explained by the amount of inputs used in production. In short, TFP measures how efficiently and intensely inputs are used in production. Which is the most appropriate measure remains a subject of debate among economists and policymakers. What is important to note is that performance across LAC remains consistently low across both measures in comparison to other regions worldwide. For example, labor productivity in Latin America grew by $0.9 \%$ annually between 1990 and 2014, compared to 1.6 , 8.1, and $2.9 \%$ for the United States, China, and Developing Asia (Bangladesh, Cambodia, Indonesia, Malaysia, Pakistan, Philippines, Sri Lanka, Thailand, and Vietnam), respectively (The Conference Board 2015). The same trend emerges when using TFP, where Latin America had negative annual growth of $0.1 \%$, compared to growth of $0.5,2.9$, and $0.4 \%$ for the United States, China, and Developing Asia, respectively (The Conference Board 2015).

3. The literature has acknowledged the importance of both factors (reallocation of resources across firms and within-firm efficiency improvements) in explaining productivity growth rates. Pagés (2010) found that both factors were key to explaining the productivity gains achieved over 1990-2005 in East Asian countries.

4. Bloom et al. (2014) concluded that the establishment-level dispersion in productivity remains high in apparently homogeneous product industries even after controlling for establishment-level output prices.

5. The skewness of a probability distribution measures its level of asymmetry. In this case, the distribution of labor productivity in the manufacturing sector is more asymmetric than that in the services sector.

6. Some authors argue that there is a likely time sequence, where within-firm effects occur only after inter-firm reallocation has been made possible. In their study on Chile, Bergoeing and Repetto (2006) concluded that the reallocation effects took place earlier, and that within-plant productivity growth driven by technology adoption and innovation only contributed 
positively to aggregate productivity growth during the 1990s, after the macroeconomic reforms were consolidated. Some macroeconomic studies also appear to confirm this preliminary evidence, with between-sector and between-firm productivity effects prevailing during the early years of policy reform in LAC, during the 1970s and 1980s, and within-sector and withinfirm effects prevailing later (Pagés 2010).

7. In the 2010 round of WBES surveys in LAC, the Inter-American Development Bank financed the inclusion of additional questions on participation in public support programs. These questions asked whether firms received public funding (either partial or full) for a range of business development services ranging from quality certification, creation of business alliances, innovation, export promotion, and training.

8. See www.enterprisesurveys.org/ for further information.

9. Public utilities, government services, health care, and financial services sectors are not included.

10. Some of the key IDB-financed variables are: product and process innovation; sales from innovative products and/or processes; R\&D spending; cooperation on innovation activities; publicly financed training programs (1) to obtain quality certification, (2) to make business alliances, (3) to support innovation, (4) to support exports, or (5) on ICTs; publicly funded external and internal training; type of workers trained; average number of hours of training sessions; and the reason no training was carried out.

11. One of the main advantages of using PPP exchange rates is that they are fairly stable over time. Market exchange rates, in comparison, are more volatile and using them can produce large distortions.

12. At the time of writing, EPFE cross-sectional data was available for the Bahamas, Colombia, Honduras, Panama, and Uruguay from surveys collected between 2011 and 2013.

13. The PROTEQin was commissioned by the IDB with funding from the Compete Caribbean Program, a regional private sector development and technical assistance initiative financed by the IDB, the United Kingdom Department for International Development, and Canada's Department of Foreign Affairs, and Trade and Development, and executed in partnership with the Caribbean Development Bank. It was administered in 2013 and 2014. For more information, see www.competecaribbean.org

\section{REFERENCES}

Álvarez, R., G. Crespi, and C. Volpe Martincus. 2012. Impact Evaluation in a Multiple Program World.. Inter-American Development Bank.

Ayyagari, M., A. Demirgüç-Kunt, and V. Maksimovic. 2012. Financing of Firms in Developing Countries. World Bank Policy Research Working Paper, No. 6036. Washington, DC: The World Bank. 
Bergoeing, R., and A. Repetto. 2006. Micro Efficiency and Aggregate Growth in Chile. Cuadernos de Economía 43(127): 169-191.

Bloom N., E. Brynjolfsson, L. Foster, R. Jarmin, M. Patnaik, I. Saporta-Eksten, and J. Van Reenen. 2014. IT and Management in America. Discussion Paper No. 1258. London, UK: Centre for Economic Performance.

Busso, M., L. Madrigal, and C. Pagés. 2013. Productivity and Resource Misallocation in Latin America. The BE Journal of Macroeconomics 13(1): 903-932.

Crépon, B., E. Duguet, and J. Mairesse. 1998. Research, Innovation and Productivity: An Econometric Analysis at the Firm Level. Economics of Innovation and New Technology 7(2): 115-158.

Crespi, G., E. Fernández-Arias, and E. Stein (eds.). 2014. Rethinking Productive Development: Sound Policies and Institutions for Economic Transformation. Washington, DC: Palgrave Macmillan for Inter-American Development Bank.

Crespi, G., and P. Zúñiga. 2012. Innovation and Productivity: Evidence from Six Latin American Countries. World Development 40(2): 273-290.

Dollar, D., M. Hallward-Driemeier, and T. Mengistae. 2005. Investment Climate and Firm Performance in Developing Economies. Economic Development and Cultural Change 54(1): 1-31.

Dosi, G. 1988. Sources, Procedures, and Microeconomic Effects of Innovation. Journal of Economic Literature 26(3): 1120-1171.

Easterly, W., and R. Levine. 2001. What Have we Learned from a Decade of Empirical Research on Growth? It's Not Factor Accumulation: Stylized Facts and Growth Models. The World Bank Economic Review 15(2): 177-219.

ECLAC. 2014. International Trade and Inclusive Development: Building Synergies. Santiago: United Nations.

Ericson, R., and A. Pakes. 1989. An Alternative Theory of Firm and Industry Dynamics. Discussion Paper 445. New York: Columbia University.

Feenstra, R.C., R. Inklaar, and M.P. Timmer. 2015. The Next Generation of the Penn World Table. American Economic Review 105(10): 3150-3182.

Fernández-Arias, E. 2014. Productivity and Factor Accumulation in Latin America and the Caribbean: A Database. Departamento de Investigación, Banco Interamericano de Desarrollo, Washington, DC. Available in: http://www. iadb.org/research/pub_desc.cfm?pub_id=DBA-015, accessed 31 August 2015.

Foster, L., J. Haltiwanger, and C.J. Krizan. 2001. Aggregate Productivity Growth: Lessons from Microeconomic Evidence. In New Developments in Productivity Analysis, ed. C.R. Hulten, E.R. Dean, and M.J. Harper. Chicago, IL: University of Chicago Press.

Hall, R.E., and C.I. Jones. 1999. Why Do Some Countries Produce So Much More Output Per Worker Than Others? Working Paper 6564. Cambridge, MA: The National Bureau of Economic Research. 
Heckman, J.J., L. Lochner, and C. Taber, 1998. Tax Policy and Human Capital Formation. National Bureau of Economic Research.

Hsieh, C.T., and P.J. Klenow. 2009. Misallocation and Manufacturing TFP in China and India. Quarterly Journal of Economics 124(4): 1403-1448.

Jovanovic, B. 1982. Selection and the Evolution of Industry. Econometrica 50(3): 649-670.

Katz, J. (ed.). 1987. Technology Generation in Latin American Manufacturing Industries. London, UK: Macmillan Press.

Klenow, P., and Rodriguez-Clare, A. 1997. The Neoclassical Revival in Growth Economics: Has It Gone Too Far? In NBER Macroeconomics Annual 1997, Volume 12 (pp. 73-114). MIT Press.

Lall, S. 1992. Technological Capabilities and Industrialization. World Development 20: 165-186.

Lavopa, A. 2015. Structural Transformation and Economic Development. Can Development Traps Be Avoided? Doctoral Thesis. The Netherlands: Maastricht University.

Lundvall, B.A. 1992. National Systems of Innovation: Towards a Theory of Innovation and Interactive Learning. London: Pinter.

Malerba, F. 2002. Sectoral Systems of Innovation and Production. Research Policy 31(2): 247-264.

McMillan, M., D. Rodrik, and Í. Verduzco-Gallo. 2014. Globalization, Structural Change, and Productivity Growth, With an Update on Africa. World Development 63: 11-32.

Nelson, R.R. 1991. Why Do Firms Differ, and How Does It Matter? Strategic Management Journal 12(S2): 61-74.

Nelson, R.R., and S.G. Winter. 1982. An Evolutionary Theory of Economic Change. Cambridge, MA: Harvard University Press.

Pagés, C. (ed.). 2010. The Age of Productivity: Transforming Economies from the Bottom Up. Washington, DC: Palgrave Macmillan for Inter-American Development Bank.

Solimano, A., and R. Soto. 2006. Economic Growth in Latin America in the Late Twentieth Century: Evidence and Interpretation. In Vanishing Growth in Latin America, ed. A. Solimano. Northampton, MA: Edward Elgar.

Syverson, C. 2011. What Determines Productivity? Journal of Economic Literature 49(2): 326-365.

Teece, D., and G. Pisano. 1994. The Dynamic Capabilities of Firms: An Introduction. Industrial and corporate change 3(3): 537-556.

The Conference Board. 2015. Total Economy Database, available at https://www. conference-board.org/data/economydatabase/, accessed 31 August 2015.

Vuletin, G.J. 2008. Measuring the Informal Economy in Latin America and the Caribbean. Working Paper 102. Washington, DC: International Monetary Fund. 
Williamson, O.E. 1973. Markets and Hierarchies: Some Elementary Considerations. American Economic Review 63(2): 316-325.

Williamson, O.E. 1985. The Economic Institutions of Capitalism: Firms, Markets, Relational Contracting. New York: Free Press.

World Bank. 2010. World Bank Enterprise Surveys (WBES). Available at: http:// www.enterprisesurveys.org. Washington, DC. The World Bank.

(c) (i) $(\Theta$ Except where otherwise noted, this work is licensed under a Creative BY NC ND Commons Attribution-NonCommercial-NoDerivatives 3.0 IGO License. To view a copy of this license, visit https://creativecommons.org/licenses/ by-nend/3.0/igo/ 